POLLACK PERIODICA

An International Journal for Engineering and Information Sciences

DOI: $10.1556 / 606.2016 .11 .3 .4$

Vol. 11, No. 3, pp. 27-42 (2016)

www.akademiai.com

\title{
CITY SUCCESS INDEX, URBAN DEVELOPMENT, A POSSIBLE METHOD TO RESEARCH URBAN STRATEGY
}

\author{
Éva KOVACS
}

\begin{abstract}
Faculty of Engineering and Information Technology, University of Pécs Boszorkány u. 2, H-7624 Pécs, Hungary, e-mail: kovacs.eva@ mik.pte.hu
\end{abstract}

Received 19 March 2016; accepted 4 July 2016

\begin{abstract}
The issue of urban development requires strategic thinking. It includes selfsustainable mechanisms, strengthening self-organization and financing of the cities, collectively. Nowadays cities face challenges in all three domains that necessitate strategic thinking on the local, national and EU levels alike.

This strategic thinking has to answer the questions concerning how is it possible for a city to implement developments that might have-long term and sustainable results for the inhabitants. What is the underlying logic to define, plan, implement and sustain city policy objectives? The search for the answer provides multiple evaluation methods. One of these logical frameworks is measuring the success of cities in the context of development/s related to a specific event.

The success of cities is researched and measured with numerous tools and methods. Analyses in this field are becoming more common, not only on a yearly basis but even more often.

The City Success Index - interpreted and presented in the current study - puts larger emphasis on involving and evaluating the so-called human factors, meanwhile creates a logical frame, which - due to the portfolio-analysis method's flexibility - is more 'customizable' for a city that would like to organize a world-class or international events with strong impact, and reveals the possible opportunities and threats. The methodology is able to contribute to strategy planning or for the evaluation of the event. The applied economic model as the frame of research in the approach is new, while the utilization of the result-zone developing might offer help in decision processes of several other public policy domains.
\end{abstract}

Keywords: City success index, Urban development, World-class event, European Capital of Culture program, Portfolio analysis, Urban policy 


\section{Introduction}

A key element in terms of city success is the development state of urban policy. Planned events and investments within the framework of an application for an event are all serious issues of urban development strategy. Therefore it is practical to apply a general methodology, which helps assessing the results and sustainability of related investments of future or already implemented events within a city. In addition, it might be useful if the city is able to pass its experience to other cities implementing similar events. The man objective of City Success Index (CSI) is to set up a model for evaluation of impacts and results of world class/influential international events and support a priori decision-making process.

The new and innovative approach of the concept examined below may offer new possibilities for drawing conclusions in terms of a number of public policy applications.

Nowadays, the majority of global population lives in cities. The urban life is the most important platform for humanity, since it is the domain where most people live their everyday lives, that is demonstrated by persistent growth of rate of urban population.

The vast majority of population choose urban environment on purpose as its space for living, therefore, development of cities, and their conscious development deserves more attention, in order to let cities develop in the appropriate framework [1].

\subsection{Urban development}

Urban development is crucial for society and for the world. Recognition and interpretation of processes affecting urban life provides basis for further analysis. This interpretation obviously might offer large diversity of terms, however, within the framework of this study it is essential to distinguish among standard, incremental, positive and negative processes, as it is shown in Table I.

Table I

Process interpretation

\begin{tabular}{|l|l|l|}
\hline Type/Effect & Negative & Positive \\
\hline Standard & $\begin{array}{l}\text { Usual, routine events, no } \\
\text { change in general operation of } \\
\text { the city. Ex. Living space gets } \\
\text { dirty. }\end{array}$ & $\begin{array}{l}\text { Usual, routine events, no change in } \\
\text { general operation of the city. Ex. } \\
\text { Enriching living space with } \\
\text { flowers. }\end{array}$ \\
\hline Incremental & $\begin{array}{l}\text { Non-routine events, general } \\
\text { operation of the city is totally } \\
\text { changed. Ex. in the event of } \\
\text { natural disaster. }\end{array}$ & $\begin{array}{l}\text { Non-routine events, general } \\
\text { operation of the city changes } \\
\text { totally. Ex. organization and } \\
\text { implementation of high-impact } \\
\text { international event. }\end{array}$ \\
\hline
\end{tabular}

A world-class international event, by all means, has incremental effect on the life of a city from the planning phase right to the sustainment period following the implementation period [2]. 


\subsection{Strategic planning}

Assessment of specific events or investments might seem to be sub-sequential argumentation in most cases but if a specific project is placed in the context of a city's life, it is already signified as an incremental effect in the city life, since it has the ability to fundamentally influence the life of the city's inhabitants. So primary concern of organizers of the event, the city leaders, politicians, and experts are to be able to do the following:

$\checkmark$ to define possible impacts of a specific event to the city;

$\checkmark$ to define possible context of urban politics and the specific event;

$\checkmark$ to design necessary development and implementation activities based on the city's facilities;

$\checkmark$ to ensure political support of all political factors for implementations of planned activities, [3];

$\checkmark$ to perform the above estimations and planning tasks according to various criteria;

$\checkmark$ to provide clear and complex evaluation of the event after the event in the context of long-term development of the city.

The complexity and difficulties of the task is demonstrated in Fig. 1.

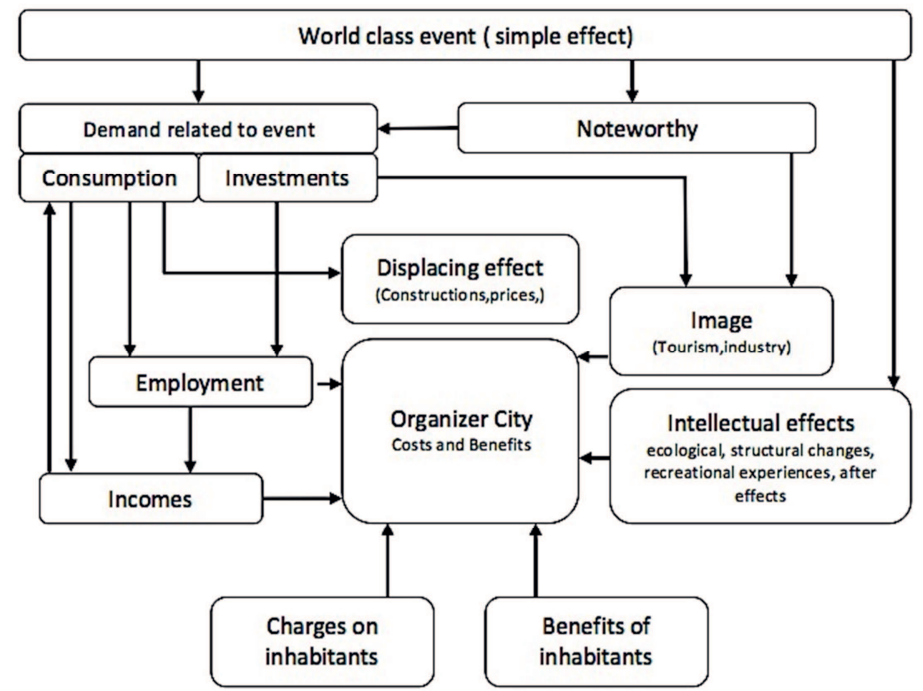

Fig. 1. Effects of world-class international events on organizer city, (on the basis of [4])

The above concept in summary is based on functioning of the city, difficulties of multiple approach evaluation and effects of the events. Professional, political and social actors of the specific city have important role in the planning phase, and first of all, in the application preparation phase. In the case of academic cities, university citizens and young creatives might be determining participants in the planning phase [5]. 
The impact of the event on the city might become more predictable with the application of a proper planning and evaluation model and at the same time the city itself might be able to achieve maximum benefit available. In this study the new term of CSI is proposed to apply as a planning and evaluation model.

\section{City development indexes and methods}

Functioning of an extremely complex system as city development cannot be assessed based on randomly selected data, the assessment and analysis method has to comply with the complexity of the system.

Difficulty in measuring stems basically from selection of appropriate criteria: it might be possible that a specific city would be ranked first concerning 'access to markets' in a recognized city evaluation list [6], while the same city would not be among the top 30 in respect of confidence in business'. Perhaps this difficulty is even clearer if it is revealed, that this city is eventually London.

The next models had been chosen as representative evaluation methods of city developments, but neither of them is based on evaluation of world-class/influential international event organization process.

\subsection{Novel approach in the model}

City development evaluation criteria, due to their nature, is based on past results and with this knowledge establishing rankings among the cities [6], [7], [8], [9] is allowed. A novel approach is applied concerning city development assessment in the interesting study compiled by the Regional Research Centre [10]. According to that, rejuvenation capability of a city is embodied in various facilities of it; an integrated model in the following would be included:

- financial and material determining factors of innovation (e.g. household- and institution-based economic development, institutions, employment and unemployment);

- human resources potential (e.g. education, highly qualified labor market segment weight, higher education, research and development);

- and local presence of innovative practices together with the proper support institution system (e.g. patents, institutions that support innovation, Research and Development (R\&D) sector weight).

In the evaluation of city rejuvenation capability criteria the following aspects have been applied by the above mentioned study, see Table II, Table III.

\subsection{Mercer model}

The next model demonstrates the concept of Mercer research institution. The company publishes research in various topics per year or in shorter periods. Mercer conducts regular and public researches based on industry sector development trends, payment rates, continent specifications, prices and other aspects [11]. (The company 
carries out research activities based on custom orders as well, that is obviously not available to the public). Mercer published in 2015 the list of the most livable cities where Vienna is ranked first, Budapest and Ljubljana are both in the 75th position - in that research 39 aspects have been considered in the following 10 categories when creating the ranking, as it is shown in Table $I V$.

\section{Table II}

Capability evaluation aspects of city rejuvenation, (on the basis of [9, pp. 118])

\begin{tabular}{|c|c|}
\hline Main component & Components \\
\hline $\begin{array}{l}\text { Economic main } \\
\text { component, economic } \\
\text { development index }\end{array}$ & $\begin{array}{l}\text { Employment rate in population } \\
\text { Number of passenger cars per } 1000 \text { inhabitants } \\
\text { Proportion of taxpayers in permanent population } \\
\text { Ratable value per inhabitant (personal income tax) } \\
\text { Number of main telephone lines per } 1000 \text { inhabitants } \\
\text { Number of enterprises with legal entities per } 1000 \\
\text { inhabitants } \\
\text { Unemployment rate in population } \\
\text { Proportion of inactive earners in population } \\
\text { Local business tax per inhabitant } \\
\text { Number of lawyers per } 10.000 \text { inhabitants }\end{array}$ \\
\hline $\begin{array}{l}\text { Education and } \\
\text { management main } \\
\text { component developed } \\
\text { labor market }\end{array}$ & $\begin{array}{l}\text { Employment rate of managers, intellectual occupations of } \\
\text { total employment } \\
\text { Employment rate of academic and higher education } \\
\text { inhabitants of total employment } \\
\text { Employment rate of other intellectual professionals of total } \\
\text { employment } \\
\text { Employment rates in service sectors of total employment }\end{array}$ \\
\hline $\begin{array}{l}\text { Social activity main } \\
\text { component - active voting } \\
\text { behavior, virulent civil } \\
\text { society, complex local } \\
\text { public forums }\end{array}$ & $\begin{array}{l}\text { Participation rate at EU referendum } \\
\text { Amount of PIT non-profit } 1 \% \text { offering per inhabitant } \\
\text { Number of NGOs per } 1000 \text { inhabitants } \\
\text { Complexity of local public forums } \\
\text { (television+radio+publishing+press) }\end{array}$ \\
\hline
\end{tabular}

The above research and ranking evaluate the cities on the global scale based on the above criteria. This approach is very close to the one in European Cities Monitor [4] prepared by the Cushman and Wakefield research institute, in which European cities are analyzed: similar aspects are evaluated by companies when a new site/branch is prepared in a different city. However, while Mercer's end results are created along onedimensional ranking, in the Cushman and Wakefield's European Cities Monitor research ranking is based on 7 categories and 21 aspects. The seven categories examined are shown in Table $V$. In this latter research essentially primary questionnaire survey method is applied: every aspect in the survey report is based on one question that has been queried by stratified sampling. Managing directors have participated as interviewees in the research. 
Table III

Capability evaluation aspects of city rejuvenation, (on the basis of [9, pp. 118])

\begin{tabular}{|l|l|}
\hline Main component & Components \\
\hline & Rate of university lecturers of total lecturers \\
& $\begin{array}{l}\text { Number of college and university faculties } \\
\text { (Faculty+off-campus training) }\end{array}$ \\
Number of secondary schools \\
Human resources main \\
$\begin{array}{l}\text { component - institutional and } \\
\text { human facilities in higher } \\
\text { education }\end{array}$ & $\begin{array}{l}\text { per 1000 inhabitants } \\
\text { Number of Hungarian Academy of Sciences public } \\
\text { body members per 10000 inhabitants } \\
\text { Number of inhabitants over 25 with university, } \\
\text { college etc. diploma } \\
\text { Number of adult education centers per 10000 } \\
\text { inhabitants }\end{array}$ \\
\hline \multirow{2}{*}{$\begin{array}{l}\text { Innovation main component - } \\
\text { complexity, density of innovation } \\
\text { institutional network, degree of } \\
\text { innovation potential }\end{array}$} & $\begin{array}{l}\text { Number of innovative initiatives } \\
\text { Number of registered domain servers } \\
\text { Number of R\&D companies }\end{array}$ \\
\cline { 2 - 3 } & $\begin{array}{l}\text { Innovation and R\&D institutional network } \\
\text { complexity index }\end{array}$ \\
\hline
\end{tabular}

\subsection{Kraft index}

The KRAFT index - that has been published in [8] - has to be highlighted when dealing with city indexes. The most important motif is that small and medium-sized cities alone can hardly be considered worthily developmental and innovation unit, returns and sustainability of investments exclusively targeted here is also problematic. Not mentioning the fact that regional developments and technical-institutional innovation cannot be regarded efficient, if it could not spread over the administrative borders of the city, county or other administrative unit. On the basis of the above it is appropriate if not essential to have a broader and more complex rethinking of development and investment concepts addressing sustainability and drawing up a new strategy. However, measurement of realization and feasibility of the new development ideas and to make these comparable is equally important. 'KRAFT index attempts to address that' [8, pp. 4].

KRAFT index reviews the opportunities of a city or a region. Opportunity would refer to that it does not describe a state, it also deals with the future - in contrast with the previous indexes: in addition to status report it analyses processes and effects based on criteria listed among others in Table VI as creativity and innovation, social capital and sustainability.

KRAFT is certainly not a nostrum; it is merely a mapping of new thinking and discussion in a new era. It aims for better understanding and more efficient shaping of complex processes within the domains of urban planning and regional development, while it might encourage the decisive actors to more profound appreciation and respect 
of each other's aspects and serve as more comprehensive and complex points of reference for the success of macro-regional strategies [8, pp. 20].

\section{Table IV}

Evaluation aspects of livable cities, (on the basis of [10])

\begin{tabular}{|c|c|}
\hline Category & Aspect \\
\hline Political and social environment & $\begin{array}{l}\text { Political stability } \\
\text { Criminality } \\
\text { Enforcement of rights }\end{array}$ \\
\hline Economic environment & $\begin{array}{l}\text { Foreign exchange regulation } \\
\text { Availability and quality of banking services }\end{array}$ \\
\hline Socio-cultural environment & $\begin{array}{l}\text { Media access } \\
\text { Censorship } \\
\text { Restriction of personal freedom }\end{array}$ \\
\hline Medical and health environment & $\begin{array}{l}\text { Health services } \\
\text { Infectious diseases } \\
\text { Sewage } \\
\text { Waste management } \\
\text { Air pollution } \\
\end{array}$ \\
\hline $\begin{array}{l}\text { Educational and training } \\
\text { environment }\end{array}$ & $\begin{array}{l}\text { School standards } \\
\text { Foreign training availability }\end{array}$ \\
\hline $\begin{array}{l}\text { Community services and } \\
\text { transportation }\end{array}$ & $\begin{array}{l}\text { Electric supply } \\
\text { Drinking water supply } \\
\text { Public transport } \\
\text { Number of traffic jams }\end{array}$ \\
\hline Recreation & $\begin{array}{l}\text { Restaurants } \\
\text { Theatres } \\
\text { Sports facilities }\end{array}$ \\
\hline Consumer goods & $\begin{array}{l}\text { Number of cars } \\
\text { Availability of personal consumer goods }\end{array}$ \\
\hline Household & $\begin{array}{l}\text { Properties for rent } \\
\text { Domestic apply supply } \\
\text { Furniture } \\
\text { Maintenance services }\end{array}$ \\
\hline Natural environment & $\begin{array}{l}\text { Climate } \\
\text { Number of natural disasters }\end{array}$ \\
\hline
\end{tabular}

\section{Table V}

Categories of city evaluation by Cushman and Wakefield (on the basis of [6])

\begin{tabular}{|l|}
\hline Business orientation of the city \\
\hline Capacity for corporate headquarters and operation \\
\hline Confidence towards the city \\
\hline City promotion value \\
\hline Target of European business expansion \\
\hline Corporate headquarters in the event of worldwide business expansion \\
\hline Impact on business (negative or positive) \\
\hline
\end{tabular}

Pollack Periodica 11, 2016, 3 
Table VI

Summary aspects of KRAFT-index (on the basis of [8])

\begin{tabular}{|l|l|}
\hline & Social creativity characteristics \\
Creativity and innovation & Creative manpower \\
potential & Creative industry \\
& Training and education \\
& 'Future university' potential \\
& Cultural, built and natural heritage (UNESCO) \\
management & ICT potential \\
& Physical infrastructure, accessibility \\
Social capital, networking & Institutions \\
potential & Conexus, interconnection \\
& Connectivity, external connections density (external \\
& networking) \\
& Values, habits \\
& Civil society potential \\
& Public trust \\
\hline \multirow{5}{*}{ Sustainability potential } & Environment protection \\
& Demography \\
& Community development \\
& Economic policy \\
& Bureaucracy, administration \\
& Attractiveness and appeal of the region \\
\hline
\end{tabular}

The objectives of creating the CSI taken into account and the forward-thinking system approach of the KRAFT index analyzing long-term processes and effects besides the results, the latter would be definitely taken as a basis for CSI that would allow its application in the urban politics decision-preparation and evaluation processes more easily.

\section{City success index, as a new model}

The above clearly show that measuring success of a city depends more on composition of the portfolio of relevant indexes, rather than prior determination of values of each index.

In the course of composition of the CSI model classic method will be applied: selection of the components to be assessed, presentation and analysis of the relations of the components and finally presentation of the model's spatial and temporal aspects.

Although it may seem rather bold at first approach, for the composition of CSI, portfolio analysis methodology applied in the domain of business-economic sciences that has been developed to support executive decisions, and applied in those cases where combined and complex analysis of multiple variables is requested for making sound strategic choices. 


\subsection{The flexible model}

The methodology provides a logical framework that is flexibly 'customized' for strategic questioning. Selection of the considered variables - irrespectively of their multitude and heterogeneity - facilitates collective analysis and with their representation complex and comprehensive evaluation can be carried out that might be rather useful when preparing decisions in urban policy concerning organization of large-scale events. The steps of model composition are shown in Fig. 2.

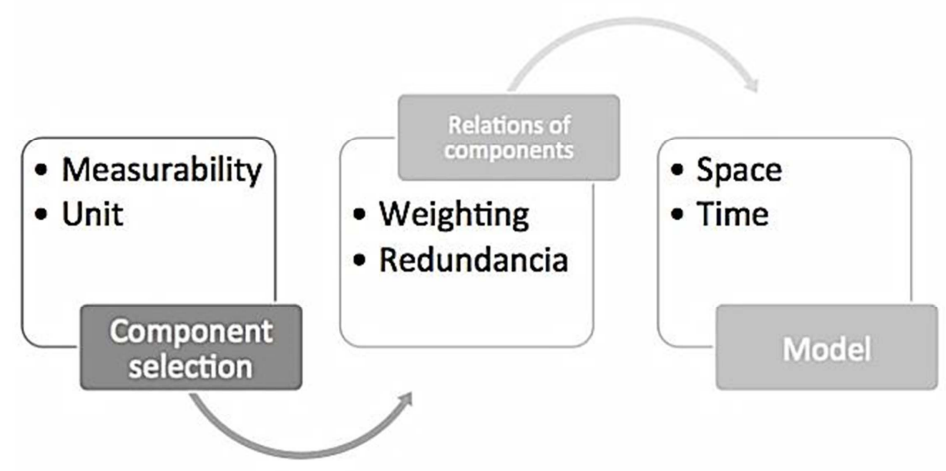

Fig. 2. The logical structure of City Success Index

It is important to express that primary objective of the methodology is decision preparation and complex comparison and analysis of the objects (cities), rather than composition of some kind of ranking.

\section{Methodology}

The composition of the CSI is based on the portfolio analysis model effectively applied in economics. In business studies the so-called multifactorial portfolio matrix is applied in several domains (marketing, leadership-management, strategic planning). Classification of the specific company's sectors is conducted in the course of business strategic planning in order to develop individual strategies and to assign appropriate resources. A company's leadership is aware that there are numerous discontinued but also several trending sectors found in their business sector (or product) portfolio [12]. However, the management cannot rely on mere impressions; they need analytical methods that allow classification of its sectors according to specific measurable feature or performance. The most common portfolio evaluation methodologies are presented in Table VII.

It needs to be stressed that the above list cannot be regarded as definitive, since

- These methodologies are based on practice: business advisors have created them for a specific task, on assignment, however they proved to be so efficient that there were multiple occasions when they have been applied. Teaching materials 
and books completed with scientific abstractions have been constructed only after these events. Boston and the surrounding business schools have integrated these practice-based modules in their MBA trainings;

- Portfolio evaluation methodologies listed in the table are considered to be only the primal ones: endless revisions, corrections have been made during the years and addressing the custom issue;

- The major advantage of these methods is followed from the above that also requires incredible responsibility from its user. The advantage comes from the fact that it provides only a framework of thought and the user decides what data would be filled in and for what purpose. Responsibility of the user of the method stems from the fact that the matrices have no strict methodological requirements, so unwarily application might easily result in constructing a model allowing to draw erroneous conclusions while the methodology is eventually correct.

\section{Table VII}

List of portfolio evaluation methodologies (on the basis of [13])

\begin{tabular}{|l|l|l|}
\hline Name & Developed by & Date \\
\hline BCG matrix & Bruce D. Henderson & 1977 \\
GE matrix & Boston Consulting Group & 1986 \\
Shell matrix & McKinsey Company & 1986 \\
ADL matrix & Shell Company & 1978 \\
\hline
\end{tabular}

In summary, in order to construct the CSI first the potential evaluation criteria and their portfolio are needed to be defined on the basis of the high-impact international events and evaluation methodologies of European Capital of Culture (ECoC) cities, including urban politics strategies influencing all these.

\subsection{Selection of dimensions}

According to the portfolio evaluation method the specific dimensions have to be developed first. In the course of development of the CSI dimensions the methodology proposed in the literature of the field [14] is followed.

One of the novelties provided by the model is the following factors taken into account and dealt with them by measurable aspects. This offers the opportunity for CSI to break away from the consciously stern city and event evaluation models analyzed in detail in the previous section.

These models fundamentally focus on the economic and business factors [6], [10], [11], [15]. The CSI composed by myself intends to focus on the person, the resident that is the active player of the cities' everyday activities. The main objective is to 'revive' the evaluation methodologies over-emphasizing the economic factors. By 'filling the model with life and people' the goal is to keep the general methodology of portfolio evaluation techniques, thus providing basis to the modification developed. Also it would 
serve as a guiding principle. The selected factors, on the basis of the above, are as follows:

- Human dimension: those aspects that have impact on the life, happiness, participation of inhabitants in urban activities, trust, satisfaction, binding, community identity and perspective, along with presenting its findings. Human dimension allows to express human factors of the CSI the most.

- Economic dimension: those aspects are able to portray the economic and business facilities of a city and its achievements. Assessment and analysis are the most popular in the literature; politics also tends to use these indexes the most.

In the application of portfolio evaluation methodology the many evaluation criteria are classified in order to identify two axes: the economic and the human one. In the next step the specific cities would be taken a position based on the scores of values of the axes, i.e. they are placed in different zones for strategy-development. This portfolio evaluation and analysis process is presented in Fig. 3 .

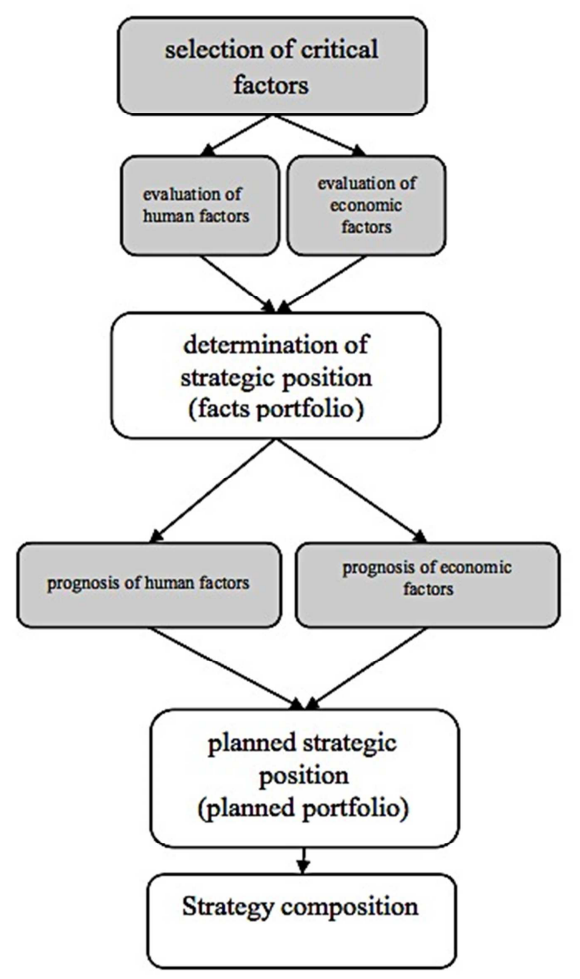

Fig. 3. The process of portfolio evaluation methodology, (on the basis of [14, pp. 181]) 
In regard of the composition of the specific dimensions I had to face the bottleneck of data availability. This means that ideal and expressive factors and criteria are not available at all or they cannot be applied. With this taken into account the following set of facts might be composed and evaluated:

\subsection{Economic factors}

The following will be considered and incorporated into CSI concerning economic factors (that specifically demonstrate the economic achievements and facilities):

- Number of highways;

- Number of sewage connections;

- Number of tourism accommodation facilities;

- Price of monthly public transport passes;

- Household income (PPS (Purchasing Power Standards)/inhabitants);

- Number of real estate businesses: numbers of businesses dealing with real estate;

- GDP/person: GDP per person (Purchasing Power Standards (PPS)/inhabitants);

- Income in trade sector: average income rate in wholesale and retail trade;

- Number of cars: registered number of cars per 1.000 inhabitants;

- Unemployment: unemployment rate (\%, inhabitants over 15 years).

\subsection{Human factors}

In regard of human factors - having impact on urban population and their lives, existence and happiness - the following will be considered and incorporated into CSI:

- Number of publishing and printing houses;

- Female ratio;

- Birth figures;

- Crime rate;

- Number of doctors;

- Number of university students;

- Number of researchers;

- Museum tickets sold;

- Number of overnight stays;

- Number of internet connections.

\subsection{Logic of the CSI model}

In the application of the portfolio evaluation methodology the various aspects are classified in order to identify the two axes. The analyst has to identify the factors providing the content of the individual axes/dimensions and has to find a method to measure these factors, and, based on that to specify final indexes.

The different axes should have high explanatory potency and also should be separated from each other in terms of logic. Individual values are assigned to the 
evaluated objects (in this case: the cities) based on the specific axes. In the area bounded by the two axes based on the explanatory potency of the axes, specific strategies for the area might be determined.

Let us take an example in which the objects are cities. One axis should be human dimension (livability) that is composed from the following factors (among others): accessibility, activities of cultural and community life, social and health care, safeness, positive attitude of the population. The other axis should be economic dimension (growth) that contains the following factors (among others): population growth, paid business tax, number of businesses, number of housing projects, GDP/person, number of factories, environment pollution rate. The individual factors might be measured based on specific criteria, e.g. accessibility might be measured based on number and quality of public transport lines, while activities of cultural and community life might be evaluated by number, attendance and popularity of cultural events. After determination of a common scale of the criteria (e.g. annual growth in percentage), average is calculated and - if valid - weighting is also performed. After aggregation concerning both axes has been conducted, two specific rates, one human (livability) and one economic (growth), are resulted regarding the city. By representing these rates on the axes, the city is displayed in the area bounded by the axes. If this area is divided into zones, the following might be identified:

- poor livability, slow-growing;

- livable, but slow-growing;

- poor livability, fast-growing;

- livable and fast-growing cities.

Distinct strategies might be developed for the particular zones, in order to strengthen the weak factors, conservation of the level of the stronger ones or even further strengthening them. As a result, depending in which zone the individual city is located, different strategies are to be applied for driving a specific city into the livable and fastgrowing zone. This analytical framework is represented in the human/economic dimension in Table VIII.

Based on the above logic, in the development of the CSI model, by the extension of the portfolio evaluation methodology, the selected dimension is allowed to be analyzed. By locating these dimensions in a co-ordinate system, the result-zones of City Success Index are represented.

It is the position occupied by the city that can be analyzed. The more objects being analyzed, the more opportunities would have to be analyzed in their relative positioning to each other as well. By comparing the positions filled by the cities in these resultzones, introducing human factors is also conducted, providing more opportunities for collective exploration of potential pitfalls and success factors that are essential for individual urban developments to fit long-term into the development strategy of the cities, also serving the demand for sustainability. 


\section{Table VIII}

CSI strategic matrix, human-economic dimensions

\begin{tabular}{|c|c|c|}
\hline low & medium & high \\
\hline $\begin{array}{l}\text { CONCENTRATION } \\
\text { Sustained investments } \\
\text { Concentration on } \\
\text { attractive human } \\
\text { segments }\end{array}$ & $\begin{array}{l}\text { SELECTIVE } \\
\text { GROWTH } \\
\text { Regional investments } \\
\text { in selected growth } \\
\text { segment } \\
\text { Sustainment of } \\
\text { attractive human } \\
\text { segments }\end{array}$ & $\begin{array}{l}\text { STRENGTHEN } \\
\text { POSITION } \\
\text { Investment for } \\
\text { achievement of } \\
\text { maximum growth } \\
\text { Regional level growth }\end{array}$ \\
\hline $\begin{array}{l}\text { CONSERVATION } \\
\text { position protection in } \\
\text { the most successful } \\
\text { segments } \\
\text { Investment } \\
\text { minimization }\end{array}$ & $\begin{array}{l}\text { SPECIALIZATION } \\
\text { Collective selection of } \\
\text { human and economic } \\
\text { segments } \\
\text { Selective investment }\end{array}$ & $\begin{array}{l}\text { DEVELOPMENT } \\
\text { Exploitation of } \\
\text { economic strengths, } \\
\text { investments based on } \\
\text { human strengths, } \\
\text { strengthening } \\
\text { vulnerabilities }\end{array}$ \\
\hline $\begin{array}{l}\text { EXIT } \\
\text { withdrawal from } \\
\text { implementation of the } \\
\text { project in the } \\
\text { application phase }\end{array}$ & $\begin{array}{l}\text { LIMITED } \\
\text { DEVELOPMENT } \\
\text { Specialization, } \\
\text { avoiding risks, Position } \\
\text { seeking, Considering } \\
\text { exit }\end{array}$ & $\begin{array}{l}\text { SELECTIVE } \\
\text { DEVELOPMENT } \\
\text { Specialization in } \\
\text { human segments } \\
\text { Exploitation of } \\
\text { economic strengths }\end{array}$ \\
\hline
\end{tabular}

Economic dimension

\section{Summary}

The above examined topic is a new and innovative approach - emergence and incorporation of the human dimension - provides previously unknown possibilities to draw conclusions and application of it in public policy.

Urban life and its quality had always prominent position throughout history for leaders, since the number of people living in urban environment and the role of opinion leaders has been very important.

Fundamental difficulties might occur when comparing multiple factors based on several aspects is to be conducted. For that reason, with the help of a properly functioning planning and evaluation model, urban development becomes more predictable by displaying all the important aspects (criteria), so the city is able to achieve the highest profit possible concerning organization of a high-impact, global event and sustainability of related investments.

The CSI might help city leaders and other experts to accurately analyze and evaluate the relations of a specific event and the city. CSI provides the opportunity for preliminary assessment concerning the expected impact (strategic planning) and also subsequent analysis by application of the portfolio evaluation methodology. CSI might 
be considered as the first step towards development of an interdisciplinary methodology dealing with several aspects for the purpose of evaluation of functioning of cities.

Economic and urban development aimed to serve the needs of the local population requires the application of new type situation analysis methods. Development of approaches is needed that are collectively based on urban traditions, statistical data and the concept of sustainability. As currently more and more business organizations express the need for responsibility thinking concerning environment, the same is becoming more and more important in the domain of urban development as well. Measurement of environment, keeping track of the vital signs of the cities and evaluation of high-impact events and investments are crucial for long-term success. Variety of the analyses provide help to describe the activities of the cities, however the primary aspect is local economic development, that is improving quality of life of the local population, providing sustainable environment, economy and society by fostering local development.

CSI described here might advocate strategic thinking of municipalities - where the aim is to realize programs and projects in the medium run based on perspectives of long-term urban development - and also might help consistent application of regional approach planning methodology. It might intensify efficient allocation of development funding, focusing of developments, avoiding fragmentation of funding and implementation. In sum, a strategy developed with the wide range of stakeholders from the politics, society and economy might be significant positional advantage for a city.

The definitive economic and political changes of today have a huge impact on individual societies. The studies of descriptive processes create the possibility for a subculture, social stratum or even cities to live with the opportunities offered by the changes, not just being mere bystanders and victims of the constant changes and its threats. The field of competitiveness is becoming more visible, along with the demand to evaluate the city success studies. The conscious planning and implementation of these are the basic pillars for those cities which would like to be successful in the emerging globalized market of attractiveness.

\section{References}

[1] Gyergyák J. Thoughts from the dynamical changing city, Shanghai, Pollack Periodica, Vol. 11, No. 1, 2016, pp. 129-143.

[2] Lienhard P., Preuss H. Legacy, sustainability and CSR at mega sport events, Springer, Wiesbaden, 2014.

[3] Kalezic T. Charter - Novi Sad Movement, Novi Sad 2021 European Capital of Culture Candidate City Conference, Novi Sad, 19-20 May 2015, pp. 1-4.

[4] Preuss H. The impact and evaluation of major sporting events, European Sport Management Quarterly, Vol. 6, No. 4, 2006, pp. 313-316.

[5] Molnár, T. Temporary city, Pollack Periodica, Vol. 5, No. 3, 2010, pp. 27-33.

[6] McCarthy F. European cities monitor, Cushman and Wakefield, Amsterdam, 2013.

[7] BuzzData, Best cities ranking and report, The Economist, London, 2012.

[8] Miszlivetz F., Márkus E. KRAFT-index, creative cities, sustainable rural region, (in Hungarian) Vezetéstudomány, Vol. 44, No. 9, 2013, pp. 2-21. 
[9] ESPON, Mapping European territorial structures and dynamics, November 2014, http://www.espon.eu/export/sites/default/Documents/Projects/ScientificPlatform/ATLAS/F INAL-REPORT_ESPON_ATLAS_2013_B.pdf, (last visited 31 January 2015).

[10] Rechnitzer J., Csizmadia Z., Grósz A. Knowledge-based rejuvenation capacity of the urban network in Hungary at the millennium (in Hungarian), Tér és Társadalom, Vol. XXVIII, No. 2, 2004, pp. 117-156.

[11] Mercer, https://www.imercer.com/content/mobility/quality-of-living-city-rankings.html (last visited 22 April 2016).

[12] Keller K. L., Kotler P. Marketing management, (in Hungarian) Akadémiai Kiadó, Budapest, 2008.

[13] Pate P., Younger M. A frame of reference for strategy development, Long Range Planning, Vol. 11, No. 2, 1978, pp. 6-12.

[14] Barakonyi K. Strategic planning, (in Hungarian), Nemzeti Tankönyvkiadó, Budapest, 1999.

[15] Best cities ranking and report, The Economist Intelligence Unit, August 2014, http://pages.eiu.com/rs/eiu2/images/EIU_BestCities.pdf, (last visited 31 January 2015). 